\title{
The Therapeutic Effects of Fenofibrate on Blood Serum Lipid in Type II Diabetic Patients in El-beida, Libya
}

\author{
Yahya Saber E. Mansour* and Nusieba A. Mohammed Ibrahim \\ Department of Pharmacology and Toxicology, Faculty of Pharmacy, Omar Al \\ Mukhtar University, Albayda, Libya.
}

Received: 4 May 2019/ Accepted: 17 November 2019

Doi: https://doi.org/10.54172/mjsc.v34i3.280

\begin{abstract}
The risks of dyslipidemia and cardiovascular diseases are well known to be increased in diabetic patients. Moreover, the therapeutic response of fenofibrate drug on blood serum lipid is also known. However, previous studies did not compare the outcomes of fenofibrate on blood serum levels in patients with type II diabetes mellitus with non-diabetic patients. The purpose of this study was to analyze the outcomes of fenofibrate on blood serum lipid profiles in hyperlipidemic patients with type II diabetes mellitus compared to hyperlipidemic patients without diabetes mellitus. This study was conducted on 40 type II diabetic patients and 30 non-diabetic patients. Their ages varied 30-55 years and all of them were hyperlipidemic. Blood serum lipid levels were measured before and once treatment at 1, 2, and 4 months. It was found that the levels of S. Total sterol and S. LDL-C were less in diabetic patients than in non-diabetic patients once they were exploited the different doses of fenofibrate, whereas the changes in S. HDL-C and S. triglyceride were nearly similar in each. Furthermore, it was noticed that just about the same responses of S. Total sterol and S. LDL-C reduction were achieved in diabetic patients once they were using a higher dose than that used for non-diabetic patients. Thus, higher doses of fenofibrate are required to reduce blood serum lipid levels in diabetic patients as compared to non-diabetic patients.
\end{abstract}

Keywords: Diabetes mellitus, lipids, fenofibrate.

\section{INTRODUCTION}

The increased risk of cardiovascular events in diabetic patients is well established (Hirano et al., 2004). Recent studies demonstrated that diabetic patients, while not having a previous coronary artery disease (CAD), had a more or less similar risk of acute coronary syndrome as non-diabetic patients with prior CAD (Hirano et al., 2004; Ikejiri et al., 2004). Several incontestable CAD patients with diabetes mellitus have higher mortality following myocardial infarction than their non-diabetic counterparts (Austin, Breslow, Hennekens, Buring, \& Willett, 1988; Ikejiri et al., 2004). Though at higher risk for future cardiovascular events, patients with CAD and diabetes are probably as those who do not have diabetes to profit from Fenofibrate as a lipid-lowering treatment. Several large trials are consistent in their findings with which CAD patients with diabetes experienced reductions in relative risk with medical treatment of comparable magnitude to the danger reductions for $\mathrm{CAD}$ patients while not having diabetes (Keating \& Ormrod, 2002; Sever et al., 2001). The results from alternative studies demonstrated the advantages of medical treatment to scale back the danger of vessel events compared with placebo in type II diabetic patient (Elisaf, 2002; Parhofer, Laubach, \& Barrett, 2003). Given their elevated risk and similar lipid management goals, one would expect CAD patients with diabetes to be treated less sharply than those non-diabetic patients. However, CAD pa-

*Corresponding Author: Yahya Saber E. Mansour Yahya.saber@Omu.edu.ly, Department of Pharmacology and Toxicology, Faculty of Pharmacy, Omar Al-Mukhtar University, Albayda, Libya. 
tients, in general, still receive optimum lipid management. Patients with diabetes could also be comparatively under-treated compared with those non-diabetic patients (Daniel, 2011; Goldberg et al., 1998). Fenofibrate is extremely effective in lowering body fluid lipid concentrations and preventing ischemic cardiovascular disease (IHD). However, we tend to not understand by what quantity fenofibrate at completely different doses affects body fluid lipid concentrations in diabetic patients as compared with nondiabetic hyperlipidemic patients.

The aim of this study was to quantify the consequences of various doses of Fenofibrate on body fluid lipid concentrations in hyperlipidemic patients with type II diabetes mellitus as compared with hyperlipidemic nondiabetic patients.

\section{MATERIALS AND METHODS}

This study was conducted in the Diabetic Clinic in El-beida city, Libya from August 2017 to November 2017 on forty (40) type II diabetic patients (20 males \& 20 females; mean age $45.5 \pm 9$ ), and thirty (30) nondiabetic patients (15 males \& 15 females; mean age $50 \pm 8.6$ ) whom fast blood serum lipid concentrations (S. Cholesterol, S. HDLC, S. LDL-C \& S. TG) were measured as a baseline, and every one of them were having hyperlipoidaemia. Lipid profiles were measured by the exploitation "Spinreact" enzymatic colorimetric test (Sever et al., 2001).

Diabetic patients were divided into two subgroups which had been administered 120mg and $160 \mathrm{mg}$ fenofibrate daily, whereas nondiabetic patients were divided into two subgroups that had been administered $120 \mathrm{mg}$ and $160 \mathrm{mg}$ fenofibrate daily, respectively. Each patient completed a 4-month follow-up period within which blood serum lipids were measured on 1, 2, and 4 months of treatment. All Diabetic patients were on treatment with oral hypoglycemic agents; 5 patients out of $40(15 \%)$ were on glibenclamide $5 \mathrm{mg}$ treatment, 10 patients $(32.5 \%)$ were on metfor- min, whereas, 18 patients $(53.5 \%)$ were on glibenclamide and metformin as a combination drug.

\section{RESULTS}

The percentages of changes in blood serum lipid concentrations in diabetic and nondiabetic patients when treated with completely different doses of fenofibrate are shown in Tables 1 to 4 and Figures 1 to 3 . It is clear from Table 1 and Fig. 1 that there were vital variations between the changes in blood serum cholesterol concentrations in diabetic and non-diabetic patients once they were treated with identical doses of fenofibrate drug. Meanwhile, it was detected that the changes in S. cholesterol concentrations in diabetics treated with $160 \mathrm{mg}$ fenofibrate were close to the changes observed in nondiabetics after they were treated with $120 \mathrm{mg}$ fenofibrate. The same observations were also applied to a large extent on the changes of $\mathrm{S}$. LDL-C concentrations shown in Table 2 and Fig. 2.

In that, there were vital differences between the changes of S. LDL-C concentrations in diabetic and non-diabetic patients after they were treated with the same doses of fenofibrate. Meanwhile, diabetic patients responding to the same degree of S. LDL-C concentration changes thereupon of non-diabetics after they were treated with higher doses used for non-diabetics. Relating to the Changes in S. HDL-C concentrations that are shown in Table 3 \& Fig 2, it was discovered that they were slightly higher in non-diabetics than in diabetic patients' exploitation of the same doses of treatment without significant differences. However, the Changes in S. triglyceride concentrations were close to being similar in diabetic and non-diabetic patients' exploitation of the same doses of treatment as shown in Table 4; Fig 3. 
Table (1). Percentage of serum level of cholesterol reduction after treatment with Fenofibrate *

\begin{tabular}{lllll}
\hline \hline \multirow{2}{*}{$\begin{array}{c}\text { Time } \\
\text { Period }\end{array}$} & \multicolumn{2}{c}{$\begin{array}{c}\text { Non-Diabetic pa- } \\
\text { tients }\end{array}$} & \multicolumn{2}{c}{$\begin{array}{c}\text { Type II Diabetic pa- } \\
\text { tients }\end{array}$} \\
\cline { 2 - 5 } & 120 & 160 & 120 & \multicolumn{1}{c}{160} \\
\hline 1 & $30.4 \% \pm$ & $49.5 \% \pm 9$ & $50.9 \% \pm$ & $46.5 \% \pm$ \\
Month & 5.5 & .5 & 5.6 & 2.9 \\
2 & $22.5 \% \pm$ & $33.7 \% \pm$ & $38.9 \%$ & $30.9 \% \pm$ \\
Month & 8.5 & 8.2 & \pm 5.4 & 5.4 \\
4 & $12.9 \% \pm$ & $20.9 \% \pm$ & $22.9 \% \pm$ & $25.4 \% \pm$ \\
Month & 9.2 & 10.5 & 10.1 & 8.2 \\
\hline \hline
\end{tabular}

Table (2). Percentage of serum level of LDL Cholesterol reduction after treatment with Fenofibrate*

\begin{tabular}{rlrll}
\hline \hline \multirow{2}{*}{$\begin{array}{c}\text { Time } \\
\text { Period }\end{array}$} & \multicolumn{2}{c}{$\begin{array}{c}\text { Non-Diabetic pa- } \\
\text { tients }\end{array}$} & \multicolumn{2}{c}{$\begin{array}{c}\text { Type II Diabetic } \\
\text { patients }\end{array}$} \\
\cline { 2 - 5 } & \multicolumn{1}{c}{120} & 160 & \multicolumn{1}{c}{120} & \multicolumn{1}{c}{160} \\
\hline 1 Month & $65.4 \% \pm$ & $68.9 \%$ & $69.3 \%$ & $65.9 \% \pm$ \\
& 3.2 & \pm 3.5 & \pm 3.2 & 3.5 \\
2 Month & $45.4 \% \pm$ & $35.2 \%$ & $44.3 \%$ & $39.9 \% \pm$ \\
& 7.5 & \pm 10.1 & \pm 5.6 & 7.8 \\
4 Month & $30.2 \% \pm$ & $28.8 \%$ & $32.1 \%$ & $22.2 \% \pm$ \\
& 8.6 & \pm 10.5 & \pm 5.5 & 10.6 \\
\hline \hline
\end{tabular}

Table (3). Percentage of serum level of HDLCholesterol elevation after treatment with Fenofibrate *

\begin{tabular}{llllc}
\hline \hline \multirow{2}{*}{$\begin{array}{c}\text { Time } \\
\text { Period }\end{array}$} & \multicolumn{2}{c}{$\begin{array}{c}\text { Non-Diabetic pa- } \\
\text { tients }\end{array}$} & \multicolumn{2}{c}{$\begin{array}{c}\text { Type II Diabetic pa- } \\
\text { tients }\end{array}$} \\
\cline { 2 - 5 } & 120 & 160 & 120 & \multicolumn{1}{c}{160} \\
\hline 1 & $3.9 \% \pm$ & $6.1 \% \pm$ & $3.9 \% \pm$ & $5.1 \% \pm 1.8$ \\
Month & 2.8 & 2.5 & 1.8 & \\
2 & $10.1 \% \pm$ & $8.9 \% \pm$ & $5.6 \% \pm$ & $4.9 \% \pm 3.2$ \\
Month & 2.5 & 2.9 & 3.6 & \\
4 & $11.3 \% \pm$ & $12.1 \% \pm$ & $8.9 \% \pm$ & $11.1 \% \pm 6.1$ \\
Month & 4.5 & 4.8 & 3.8 & \\
\hline \hline
\end{tabular}

Table 4: Percentage of serum level of triglyceride reduction after treatment with Fenofibrate *

\begin{tabular}{lllll}
\hline \hline $\begin{array}{c}\text { Time } \\
\text { Period }\end{array}$ & $\begin{array}{l}\text { Non-Diabetic } \\
\text { tients }\end{array}$ & pa- & $\begin{array}{l}\text { Type II } \\
\text { patients }\end{array}$ & Diabetic \\
\cline { 2 - 5 } & 120 & 60 & 120 & 60 \\
\hline $45.2 \% \pm$ & $45.2 \% \pm$ & $44.9 \% \pm$ & $50.9 \% \pm$ & $48.9 \% \pm$ \\
3.6 & 3.6 & 4.5 & 2.7 & 4.4 \\
$33.7 \% \pm$ & $33.7 \% \pm$ & $31.5 \% \pm$ & $44.3 \% \pm$ & $35.9 \% \pm$ \\
7.5 & 7.5 & 8.5 & 7.5 & 9.8 \\
$24.9 \% \pm \pm$ & $24.9 \% \pm$ & $20.1 \% \pm$ & $22.1 \% \pm$ & $27.2 \% \pm$ \\
$9.5 \%$ & $9.5 \%$ & 10.5 & 9.5 & 10.8 \\
\hline \hline
\end{tabular}

All data were presented as Mean \pm Standard
Deviations. Student's t-test $(\mathrm{P}<0.05)$ were considered as significant. Cholesterol; HDL-C High-density lipoprotein cholesterol; LDL-C Low-density lipoprotein cholesterol; TG Triglyceride.

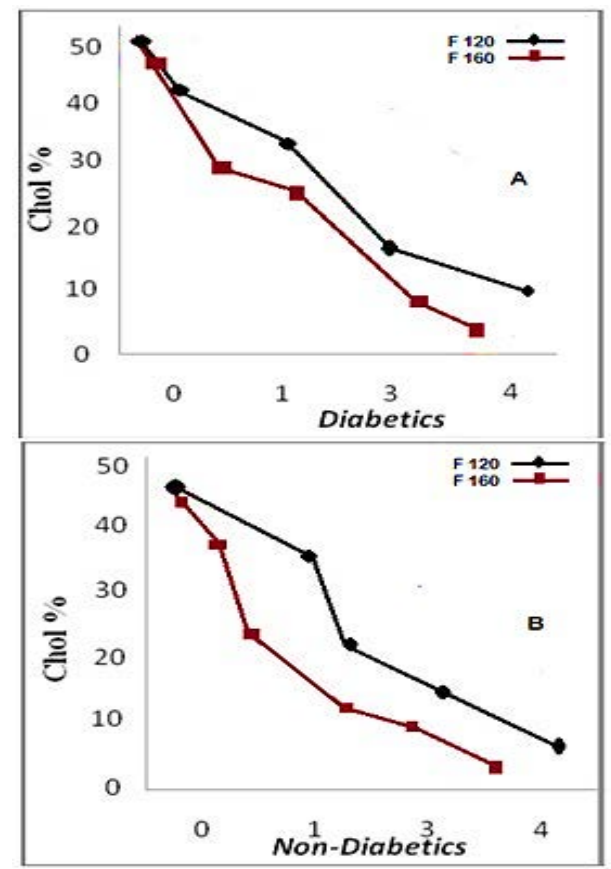

Figure 1: Line chart that represents the percentage of serum level of Cholesterol after fenofibrate treatment in Diabetic and Non-Diabetic patients

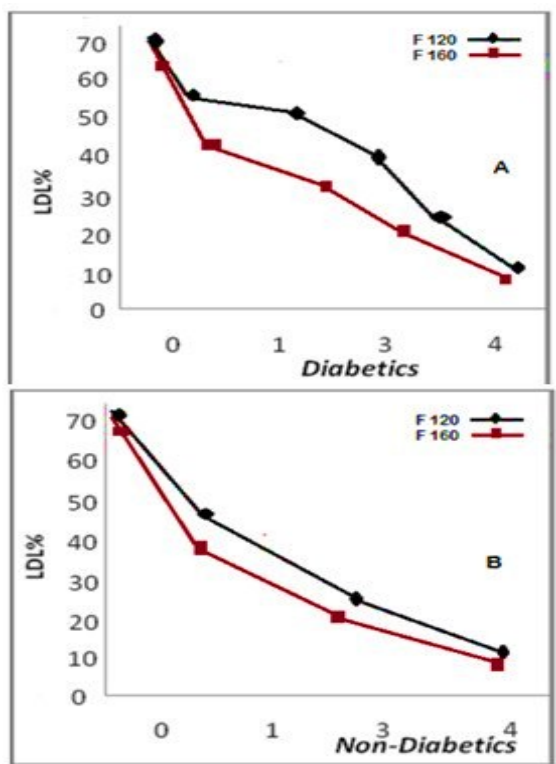

Figure 2: Line chart that represents the percentage of serum level of low-density lipoprotein after fenofibrate treatment on Diabetic and Non-Diabetic patients. 


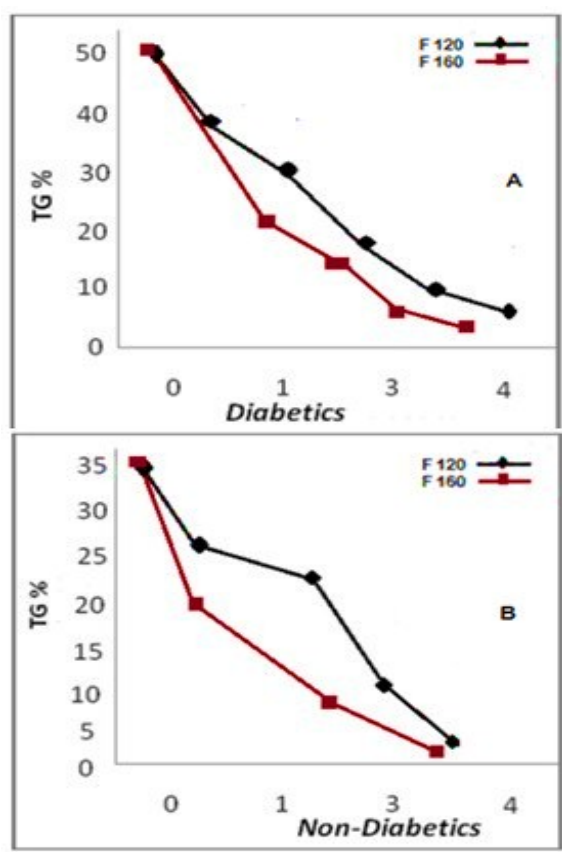

Figure 3: Line chart that represents the percentage of serum of HDL-cholesterol after fenofibrate treatment in Diabetic and Non-Diabetic patients.

\section{DISCUSSION}

This study provides evidence that the response of lipid profiles to fenofibrate in diabetic patients differs from that in nondiabetics, during which the changes in $\mathrm{S}$. Cholesterol and S. LDL-Cholesterol were less in diabetic patients than in non-diabetic patients once using the same doses of fenofibrate. Moreover, it is noticed that almost the same changes were achieved in diabetic patients once they were using higher doses that are used for non-diabetic patients. Besides, another trial was done by Law et al, showed that the reductions in cholesterol in non-diabetic patients were $(40 \%)$ with fenofibrate, $120 \mathrm{mg}$ per day (Investigators, 2001). After treatment, lipid levels for diabetic patients have improved less quickly than those for non-diabetic patients.(Massing et al., 2003), stated that mean non-HDL-C levels are already higher among patients with diabetes and did not decline as quickly for this group, which increases the gap between them and patients without diabetes (Rubins et al., 2002).

(C) 2019 The Author(s). This open access article is distributed under a CC BY-NC 4.0 license.

ISSN: online 2617-2186 print 2617-2178
Although the mean concentration of cholesterol in diabetic patients is not considerably totally different from that in people without diabetes, qualitative changes in cholesterol could also be present. Diabetic patients tend to possess a better proportion of LDL particles that are smaller and denser (Yoshino, Hirano, \& Kazumi, 2002), additional liable to chemical reaction, and should thereby increase the danger of vessel events (Elkeles et al., 1998), and may conjointly justify the difference in fenofibrate between diabetic and non-diabetic patients.

The changes in S. HDL-Cholesterol in each of diabetic and non-diabetic patients were nearly similar in spite of the less rapid improvement in diabetics. Nonetheless, they did not reach what was achieved by alternative reports like that found by Kothari et al, 2002. that stated HDL-cholesterol enlarged considerably (19\%) after four weeks of fenofibrate therapy (120mg/day) (Keating \& Ormrod, 2002). That distinction could also be as a result of that our patients were less likely to do exercise to support HDL-C elevation. Likewise, the changes in S. triglyceride were also similar in each diabetic and non-diabetic patients which was less than what was reported by Klaus et al, that fast lipids were reduced by $(45 \%)$ after four weeks of Fenofibrate medical care $(120 \mathrm{mg} /$ day) (Kothari et al., 2002). Besides, once reviewing literatures; there is no familiar drug-drug interaction between fenofibrate and oral hypoglycaemic agents (Westphal, Dierkes, \& Luley, 2001) to be chargeable for that difference in response between diabetic and non-diabetic patients.

\section{CONCLUSION}

The higher doses of fenofibrate were required to reduce blood serum lipid levels in diabetic patients as compared to non-diabetic patients.

\section{ACKNOWLEDGEMENT}

Data have been obtained from the Diabetic Clinic in El-beida city, Libya. 


\section{ETHICS}

All patients provided written permission and consent before collecting data to conduct this research study.

\section{REFERENCES}

Austin, M., Breslow, J., Hennekens, C., Buring, J., \& Willett, W. (1988). Krauss RM. Low-density lipoprotein subclass patterns and risk of myocardial infarction. Jama, 260, 1917-1921.

Daniel, M. J. (2011). Lipid management in patients with type 2 diabetes. American health \& drug benefits, 4(5), 312.

Elisaf, M. (2002). Effects of fibrates on serum metabolic parameters. Current medical research and opinion, 18(5), 269-276.

Elkeles, R. S., Diamond, J. R., Poulter, C., Dhanjil, S., Nicolaides, A. N., Mahmood, S., . . . Feher, M. D. (1998). Cardiovascular outcomes in type 2 diabetes: A double-blind placebocontrolled study of bezafibrate: The St. Mary's, Ealing, Northwick Park Diabetes Cardiovascular Disease Prevention (SENDCAP) Study. Diabetes care, 21(4), 641-648.

Goldberg, R. B., Mellies, M. J., Sacks, F. M., Moyé, L. A., Howard, B. V., Howard, W. J., . . . Braunwald, E. (1998). Cardiovascular events and their reduction with pravastatin in diabetic and glucose-intolerant myocardial infarction survivors with average cholesterol levels: subgroup analyses in the cholesterol and recurrent events (CARE) trial. Circulation, 98(23), 2513-2519.

Hirano, T., Ito, Y., Koba, S., Toyoda, M., Ikejiri, A., Saegusa, H., . . Y Yoshino, G. (2004). Clinical significance of small dense low-density lipoprotein cholesterol levels determined by the simple precipitation method. Arteriosclerosis, thrombosis, and vascular biology, 24(3), 558-563.

Ikejiri, A., Hirano, T., Murayama, S., Yoshino, G., Gushiken, N., Hyodo, T., . . . Adachi, M. (2004). Effects of atorvastatin on triglyceride-rich lipoproteins, low-density lipoprotein subclass, and C-reactive protein in hemodialysis patients. Metabolism, 53(9), 1113-1117.

Investigators, D. A. I. S. (2001). Effect of fenofibrate on progression of coronaryartery disease in type 2 diabetes: the Diabetes Atherosclerosis Intervention Study, a randomised study. The Lancet, 357(9260), 905-910.

Keating, G. M., \& Ormrod, D. (2002). Micronised fenofibrate. Drugs, 62(13), 1909-1944.

Kothari, V., Stevens, R. J., Adler, A. I., Stratton, I. M., Manley, S. E., Neil, H. A., \& Holman, R. R. (2002). UKPDS 60: risk of stroke in type 2 diabetes estimated by the UK Prospective Diabetes Study risk engine. Stroke, 33(7), 1776-1781.

Massing, M. W., Foley, K. A., Sueta, C. A., Chowdhury, M., Biggs, D. P., Alexander, C. M., \& Simpson, R. J. (2003). Trends in lipid management among patients with coronary artery disease: has diabetes received the attention it deserves? Diabetes care, 26(4), 991-997.

Parhofer, K. G., Laubach, E., \& Barrett, P. H. R. (2003). Effect of atorvastatin on postprandial lipoprotein metabolism in hypertriglyceridemic patients. Journal of lipid research, 44(6), 1192-1198.

Rubins, H. B., Robins, S. J., Collins, D., Nelson, D. B., Elam, M. B., Schaefer, 
E. J., . . Anderson, J. W. (2002).

Diabetes, plasma insulin, and cardiovascular disease: subgroup analysis from the Department of Veterans Affairs high-density lipoprotein intervention trial (VA-HIT). Archives of internal medicine, 162(22), 2597-2604.

Sever, P. S., Dahlöf, B., Poulter, N. R., Wedel, H., Beevers, G., Caulfield, M., . . . McInnes, G. T. (2001). Prevention of coronary and stroke events with atorvastatin in hypertensive patients who have average or lower-thanaverage cholesterol concentrations, in the Anglo-Scandinavian Cardiac Outcomes Trial-Lipid Lowering Arm (ASCOT-LLA): a multicentre randomised controlled trial. The Lancet, 361(9364), 1149-1158.

Westphal, S., Dierkes, J., \& Luley, C. (2001). Effects of fenofibrate and gemfibrozil on plasma homocysteine. The Lancet, 358(9275), 39-40.

Yoshino, G., Hirano, T., \& Kazumi, T. (2002). Treatment of small dense LDL. Journal of atherosclerosis and thrombosis, 9(6), 266-275. 


\section{تأثير فينوفاييرات على دهون مصل الدم في مرضى السكري من النوع الثاني}

يحيي صابر السيد منصور" ونسيبة عوض محمد إبراهيم

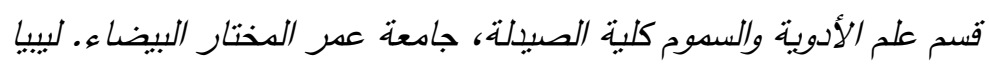

تاريخ الاستلام: 4 مايو 2019 / تاريخ القبول: 17 نوفمبر 2019 https://doi.org/10.54172/mjsc.v34i3.280:Doi

المستخلص: من المعروف جيدًا أن خطر الإصـابة باضطرابات دهون الدم وأمراض القلب الوعائية يزداد لاى مرضى السكري. بالإضـافة إلى أن الاستجابة العلاجية لعقار الفينوفاييرات على الدهون في مصل الدم معروفة أيضًا. ومـع ذلك، فإن الدراسـات السابقة لم تقارن نتائج فينوفايبرات على مستوى مصل الدم في المريض المصاب بالسكري من النوع الثاني مـع غير المصابين بالسكري. الغرض من هذه الدراسـة هو تحليل نتائج الفينوفاييرات على مستويات الدهون في الدم لدى مرضى فرط دهون الدم المصابين بداء السكري من النوع الثاني مقارنة بها لدى مرضى فرط دهون الدم غير المصابين بداء السكري، حيث أجريت هذه الدراسة على 40 مريضًا مصابًا بداء السكري من النوع الثاني و 30 مريضًا من غير المصابين بالسكري تتراوح أعمارهم بين 30 و 55 سنة وكانوا جميعًا يعانون من فرط دهون الدم. وقد تم قياس مستويات الدهون في مصل الدم قبل العلاج ومرة واحدة في الثهر 1 و 4 ون العلاج. واكتُشف أن مستويات S. Total sterol و S. LDL-C كانت أقل لدى مرضى السكري عنها لدى S. و و S. HDL- Hير المصـابين بالسكري بمجرد تتـاولهم جرعـات مختلفة مـن الفينوفايبرات، في حين أن التغييرات في كانت مماثلة تقريبًا في كليهما. وبالإضافة إلى ذلك لوحظ أنه تم التوصل إلى النتائج نفسها فيما يخص انخفاض كل من و S. Total sterol و لدى مرضى السكري بسبب نتاولهم جرعات اعلى من تلك التي يتتاولها المرضى غير المصابين بالسكري. وبالتالي لا بد من تتاول جرعات اعلى من الفينوفاييرات لتقليل مستويات الدهون في مصل الدم لاى مرضى السكري مقارنة بالمرضى غير المصابين بالسكري. الكلمات المفتاحية: مرض السكري، دهون، فينوفاييرات. 